University of Nebraska - Lincoln

DigitalCommons@University of Nebraska - Lincoln

2000

\title{
Potential Production and Environmental Effects of Switchgrass and Traditional Crops under Current and Greenhouse-Altered Climate in the Central United States: A Simulation Study
}

\author{
R.A. Brown \\ Battelle, Pacific Northwest National Laboratory, 901 D Street, S.W., Suite 900, Washington, DC \\ N.J. Rosenberg \\ Battelle, Pacific Northwest National Laboratory, 901 D Street, S.W., Suite 900, Washington, DC \\ Cynthia J. Hays \\ University of Nebraska - Lincoln, chays1@unl.edu \\ W.E. Easterling \\ Department of Geography, The Pennsylvania State University, University Park, PA 16802, USA \\ L.O. Mearns \\ The National Center for Atmospheric Research, 1850 Table Mesa Drive, Boulder, C0 80307, USA
}

Follow this and additional works at: https://digitalcommons.unl.edu/natrespapers

Part of the Natural Resources and Conservation Commons

Brown, R.A.; Rosenberg, N.J.; Hays, Cynthia J.; Easterling, W.E.; and Mearns, L.O., "Potential Production and Environmental Effects of Switchgrass and Traditional Crops under Current and Greenhouse-Altered Climate in the Central United States: A Simulation Study" (2000). Papers in Natural Resources. 155.

https://digitalcommons.unl.edu/natrespapers/155

This Article is brought to you for free and open access by the Natural Resources, School of at DigitalCommons@University of Nebraska - Lincoln. It has been accepted for inclusion in Papers in Natural Resources by an authorized administrator of DigitalCommons@University of Nebraska - Lincoln. 


\title{
Potential production and environmental effects of switchgrass and traditional crops under current and greenhouse-altered climate in the central United States: a simulation study
}

\author{
R.A. Brown ${ }^{\text {a,* }}$, N.J. Rosenberg ${ }^{\text {a }}$, C.J. Hays ${ }^{b}$, W.E. Easterling ${ }^{c}$, L.O. Mearns ${ }^{d}$ \\ ${ }^{a}$ Battelle, Pacific Northwest National Laboratory, 901 D Street, S. W., Suite 900, Washington, DC 20024-2115, USA \\ ${ }^{\mathrm{b}}$ Department of Agricultural Meteorology, 236 L.W. Chase Hall, University of Nebraska, Lincoln, NE 68583-0728, USA \\ c Department of Geography, The Pennsylvania State University, University Park, PA 16802, USA \\ d The National Center for Atmospheric Research, 1850 Table Mesa Drive, Boulder, CO 80307, USA \\ Received 5 January 1999; received in revised form 12 July 1999; accepted 30 July 1999
}

\begin{abstract}
If, as many climate change analysts* speculate, industrial and other emissions of $\mathrm{CO}_{2}$ can be offset by substitution of biofuels, large areas of land, including agricultural land, may be converted to the production of biomass feedstocks. This paper explores the feasibility for the Missouri-Iowa-Nebraska-Kansas (MINK) region of the US of converting some agricultural land to the production of switchgrass (Panicum virgatum L.), a perennial warm season grass, as a biomass energy crop. The erosion productivity impact calculator (EPIC) crop growth model simulated production of corn (Zea mays L.), sorghum (Sorghum bicolor (L.) Moench), soybean (Glycine max L.), winter wheat (Triticum aestivum L.) and switchgrass at 302 sites within the MINK region. The analysis is done for both current climatic conditions and a regional climate model-based scenario of possible climate change. Daily climate records from 1983 to 1993 served as baseline and the NCAR-RegCM2 model (RegCM hereafter) nested within the CSIRO general circulation model (GCM) provided the climate change scenario. Crop production was simulated at two atmospheric $\mathrm{CO}_{2}$ concentrations $\left(\left[\mathrm{CO}_{2}\right]\right)$ at 365 and $560 \mathrm{ppm}$ to consider the $\mathrm{CO}_{2}$-fertilization effect. Simulated yields of the perennial switchgrass increased at all sites with a mean yield increase of $5.0 \mathrm{Mg} \mathrm{ha}^{-1} \mathrm{under}$ the $\mathrm{RegCM}$ climate change scenario. Switchgrass yields benefited from temperature increases of 3.0-8.0 ${ }^{\circ}$, which extended the growing season and reduced the incidence of cold stress. Conversely, the higher temperatures under the RegCM scenario decreased yields of corn, soybean, sorghum and winter wheat due to increased heat stress and a speeding of crop maturity. With no $\mathrm{CO}_{2}$-fertilization effect, EPIC simulated maximum decreases from baseline of $1.5 \mathrm{Mg} \mathrm{ha}^{-1}$ for corn, $1.0 \mathrm{Mg} \mathrm{ha}^{-1}$ for sorghum, $0.8 \mathrm{Mg} \mathrm{ha}^{-1}$ for soybean and $0.5 \mathrm{Mg} \mathrm{ha}^{-1}$ for winter wheat. Simulated yields increased for all crops under the RegCM scenario with $\mathrm{CO}_{2}$ set to $560 \mathrm{ppm}$. Yields increased above baseline for $34 \%$ of the soybean and $37 \%$ of the winter wheat farms under RegCM/ $\left[\mathrm{CO}_{2}\right]=560 \mathrm{ppm}$ scenario. Water use increased for all crops under the higher temperatures of the CSIRO scenario. Precipitation increases resulted in greater runoff from the traditional crops but not from switchgrass due to the crop's increased growth and longer growing season. Simulated soil erosion rates under switchgrass and wheat cultivation
\end{abstract}

\footnotetext{
* Corresponding author. Tel.: +1-202-646-5204; fax: +1-202-646-5233.

E-mail address: robbie.brown@pnl.gov (R.A. Brown).
} 
were less severe than under corn management. However, simulated erosion under switchgrass was considerable in eastern Iowa during the period of crop establishment because of strong winds at that time.

Keywords: Biomass energy; Climate change; Central US; Switchgrass; EPIC

\section{Introduction}

Biomass-based energy systems have been proposed as a means of reducing greenhouse gas emissions (e.g. Hall et al., 1990; Graham et al., 1992; Hall et al., 1993; Wright and Hohenstein, 1994) when substituted for traditional fossil fuels. Such systems are carbon neutral since, when combusted, biomass returns to the atmosphere $\mathrm{CO}_{2}$ recently captured by the feedstock. There are, of course, $\mathrm{CO}_{2}$ costs embedded in the inputs (e.g., fertilizer, diesel fuel) required in biomass production but there are also savings in the sequestration of carbon in the soil. Biomass energy can be produced from short rotation woody crops, herbaceous energy crops, halophytes, some annual crops and oilseeds.

The economic and environmental consequences of large-scale biomass production are viewed as positive or manageable by a number of analysts. Sampson et al. (1993) conclude that dedicated energy crops could reduce carbon emissions to the atmosphere from 0.2 to $1.0 \mathrm{Gt} \mathrm{year}^{-1}$. Hall (1997) projects a biomass contribution of $17-30 \%$ of global energy requirement up to 2050. Graham et al. (1996) applied an analytical assessment framework to two Tennessee regions and concluded that dedicated energy crops in place of conventional crops would significantly reduce erosion and chemical runoff. While biomass crops offer potential benefits, the conversion of large areas of productive agricultural lands to this use has possible downsides as well. The most serious of these is the competition for land that large-scale biomass culture will create. Rosenberg and Scott (1994) surveyed data that bear on this question. Some examples: an area of 465 million hectares - almost as large as the trans-Mississippi west - would have to be re- or afforested to offset the annual increase in atmospheric $\mathrm{CO}_{2}$ emissions (Sedjo and Solomon, 1989); an area of 90.7 million hectares of new forests or $48 \%$ of all US croplands would be required to offset $50 \%$ of the $1.27 \mathrm{Gt} \mathrm{year}^{-1}$ annual US emissions of carbon (Moulton and Richards, 1990). Giampietro et al. (1997) believe that large-scale biomass production will greatly stress available supplies of land and water everywhere and reverse economic progress in developing countries.

It is evident, then, that biomass production on a scale that will permit a significant substitution of fossil fuels cannot be accomplished on marginal lands alone but will require large areas of prime agricultural land and the substitution of biomass crops for crops currently grown in some regions. Whether or not a particular biomass crop, switchgrass, can substitute for traditional crops in an important agricultural region, the Missouri-Iowa-Nebraska-Kansas (MINK) region of the central US, and whether or not climate change will favor such a substitution is evaluated here. Results are presented on a simulation study comparing the yield potential of switchgrass, its water use and effects on soil erosion with those of the region's dominant agricultural crops - corn, sorghum, soybeans and winter wheat. The comparison is made for current climatic conditions (baseline) and for a scenario of greenhouse-forced climate change with and without a $\mathrm{CO}_{2}$-fertilization effect.

\section{Methods and materials}

The erosion productivity impact calculator (EPIC) (Williams, 1995), the crop growth simulator used in this study, is described in this section as are the input datasets that it requires. Brown et al. (1998) provides a more detailed description of EPIC and representative farms used in this study.

\subsection{EPIC model description}

EPIC (ver. 5320) is a process-based model that simulates soil erosion and crop productivity. The model runs on a daily time step at the scale of a single field. EPIC requires soil properties (e.g., bulk density, wilting point, water holding capacity) and crop management (e.g., cultivars, fertilization, tillage) as inputs. 
Daily values of precipitation, minimum/maximum air temperature, solar radiation, windspeed and relative humidity drive EPIC. The model simulates bio-physical processes encompassing an agricultural system such as photosynthesis evapotranspiration, runoff, water erosion and wind erosion.

EPIC models a wide range of crops using parameters specific to each crop. The crop growth model uses radiation use efficiency to calculate the potential daily photosynthetic production of biomass. The daily potential is decreased by stresses caused by shortages of radiation, water and nutrients, by temperature extremes and by inadequate soil aeration in proportion to the severity of the most severe stress for that day. Atmospheric $\mathrm{CO}_{2}$ concentration $\left(\left[\mathrm{CO}_{2}\right]\right)$ affects stomatal conductance. Stomatal conductance affects radiation use efficiency and water use efficiency and, as a result, photosynthesis and evapotranspiration. Stockle et al. (1992a, b) adapted EPIC to simulate the $\mathrm{CO}_{2}$-fertilization effect on plant photosynthesis and transpiration. Crop maturity is determined by the accumulation of heat units during the growing season. Crop yields are estimated by multiplying above-ground biomass at maturity by a harvest index (proportion of total biomass in harvested organs) for the particular crop. For additional details on EPIC as it is used in climate change impact simulations, see Brown and Rosenberg (1997, 1999).

\subsection{The study area and climate scenarios}

A high resolution climate change scenario for the US (Mearns et al., 1996) provided the climate change scenario. Giorgi et al. (1998) employed the NCAR-RegCM2 regional climate model (RegCM) nested within a GCM and run at a $50 \mathrm{~km}$ grid point spacing. The RegCM receives lateral and initial boundary conditions from a GCM. The CSIRO model (Watterson et al., 1995) was chosen in this application because of its ability, relative to other available GCMs, to reproduce historic climate over the central United States. The RegCM network encompasses a network of $30250 \times 50 \mathrm{~km}$ grid boxes (Fig. 1). This fine-scale grid allows simulation of switchgrass and the traditional crops in sufficient detail to explore variability due to geography, climate, soils and farm management. A 10-year daily climate record was created for both the control and the climate change scenario. The latter is based on the assumption of an effective doubling of the preindustrial atmospheric $\mathrm{CO}_{2}$ concentration $\left(2 \times \mathrm{CO}_{2}\right.$ climate $)$. Differences between the control and $2 \times \mathrm{CO}_{2}$ climates were then applied to the baseline of each grid box to create its climate change scenario.

\subsection{EPIC representative farms}

A set of 'representative farms' was developed to describe agricultural practices and environmental conditions in each of the 302 grid boxes. The representative farm design stems from an earlier study of the MINK region (Easterling et al., 1992; Rosenberg, 1993) and subsequent follow-up analyses (Easterling et al., 1998). A subset of eight farms identified in Fig. 1 is used to provide details on the mechanisms that determine crop response under current and changed climate. Table 1 presents the location of these farms, their soils and some climatic data.

Daily climate records from the National Weather Service Cooperative Climate Network provided baseline precipitation and minimum/maximum temperature data from 1983 to 1993 . Daily solar radiation, relative humidity and windspeed records were assembled with the EPIC weather generator (WXGEN) of

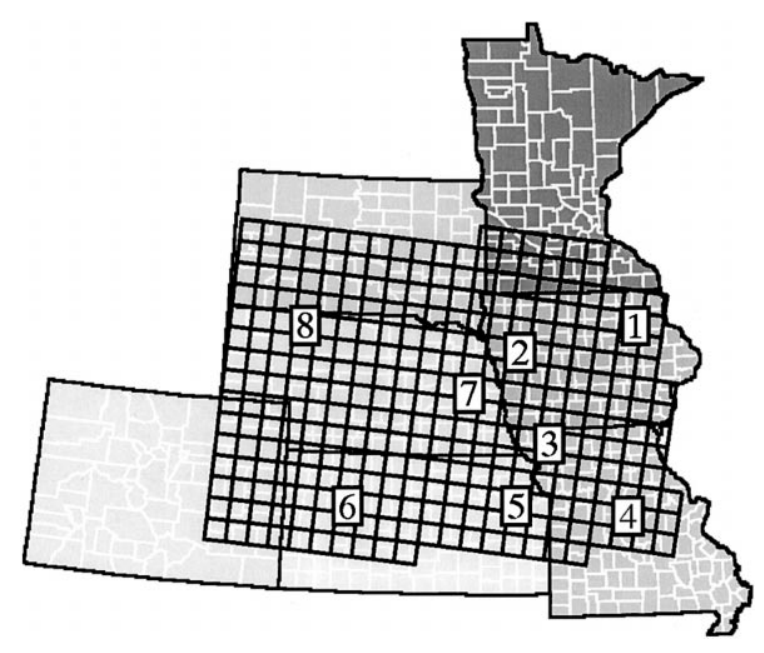

Fig. 1. The RegCM grid network and its orientation with respect to the MINK region. The numbered boxes identify the subset of representative farms discussed and described in Section 3. 
Table 1

Location, climate and soil series of the subset of representative farms identified in Fig. 1

\begin{tabular}{|c|c|c|c|c|c|c|c|c|c|c|}
\hline \multirow[t]{2}{*}{ Farm } & \multirow[t]{2}{*}{ \# State } & \multirow[t]{2}{*}{$\begin{array}{l}\text { Climate } \\
\text { station }\end{array}$} & \multicolumn{3}{|c|}{$\begin{array}{l}\text { Soil } \\
\text { identification }\end{array}$} & \multirow{2}{*}{$\begin{array}{l}\text { North } \\
\text { latitude } \\
\left({ }^{\circ}\right)\end{array}$} & \multirow{2}{*}{$\begin{array}{l}\text { West } \\
\text { longitude } \\
\left({ }^{\circ}\right)\end{array}$} & \multirow{2}{*}{$\begin{array}{l}\text { Annual } \\
\text { precipitation } \\
(\mathrm{mm}) \text { (total) }\end{array}$} & \multirow{2}{*}{$\begin{array}{l}\text { Annual } \\
\text { maximum } \\
\text { temperature } \\
\left({ }^{\circ} \mathrm{C}\right)\end{array}$} & \multirow{2}{*}{$\begin{array}{l}\text { Annual } \\
\text { minimum } \\
\text { temperature } \\
\left({ }^{\circ} \mathrm{C}\right)\end{array}$} \\
\hline & & & Series nam & Soil taxonomy & FAO taxonomy & & & & & \\
\hline 1 & Iowa & Fayette & Clyde & Typic Haplaquolls & Mollic Gleysol & 42.8 & 92.2 & 883 & 13.8 & 2.5 \\
\hline 2 & Iowa & Castana & Napier & Cumulic Hapludolls & Pachic Phaeozom & 42.3 & 95.5 & 811 & 15.5 & 3.6 \\
\hline 3 & Missouri & Conception & Colo & Cumulic Endoaquolls & Mollic Gleysol & 40.3 & 94.6 & 882 & 17.2 & 4.7 \\
\hline 4 & Missouri & Columbia & Hartwell & Typic Argialbolls & Mollic Planosol & 38.6 & 92.5 & 1064 & 19.2 & 7.1 \\
\hline 5 & Kansas & Oskaloosa & Martin & Aquertic Argiudolls & Vertic Phaeozom & 40.0 & 95.5 & 935 & 18.8 & 6.8 \\
\hline 6 & Kansas & Quinter & Ulysses & Aridic Haplustolls & Calcic Chernozem & 38.9 & 100.3 & 569 & 18.6 & 4.3 \\
\hline 7 & Nebraska & Clarkston & Moody & Udic Haplustolls & Haplic Kastanozem & 41.5 & 96.9 & 765 & 16.3 & 3.7 \\
\hline 8 & Nebraska & Merriman & Valentine & Typic Ustipsamments & Eutric Arenosol & 42.7 & 101.8 & 465 & 16.4 & 0.9 \\
\hline
\end{tabular}

Richardson and Nicks (1990) using monthly averages from the nearest National Weather Service (NWS) first order station. Soil properties were derived from the STATSGO (USDA, 1992) and EPIC (Williams et al., 1990) databases. Tillage practices employed with corn, sorghum, soybean and winter wheat were derived from the agricultural sector model (ASM) crop budgets for 1996 (McCarl et al., 1998). A series of switchgrass field experiments (Anderson, 1989; Anderson and Shapiro, 1990; Mitchell et al., 1994) provided a single switchgrass management budget for the entire region. Only one mid-summer harvest was simulated for switchgrass, although two harvests may be more appropriate in southern Missouri and Kansas.

\section{Results}

\subsection{Validation of EPIC}

\subsubsection{Traditional crop simulations}

EPIC simulations of crop yield have been extensively validated against actual crop yields. Kiniry et al. (1990) found agreement between simulated and actual yields of corn, wheat, rice, soybean, barley and sunflower under a variety of management systems and climatic conditions. Rosenberg et al. (1992) compared EPIC-simulated yields with historic county yields, yields from agronomic experiments and yield estimates by local agricultural experts and concluded that EPIC is suitable for simulating agricultural production in the MINK region. Easterling et al. (1998) reported that EPIC simulations of representative farms with soils and climate data on a $0.5^{\circ}$ grid scale explained $65 \%$ of the annual variation in eastern Iowa corn and 54\% in western Kansas wheat yields.

The validation exercises described above employed earlier versions of EPIC, and the crop budgets, soils and climates of the representative farms differed slightly from those used here. Given the previous work, the goal of this validation was modest: to determine if EPICs algorithms and the representative farm descriptions generally agree with regional historic yields and accurately predict regional yield patterns.

Results of the yield simulations for dryland corn, sorghum, soybean and winter wheat on a subset of 13 representative farms ( 8 of which are identified in Fig. 1) are compared in Fig. 2 to USDA-NASS county mean crop yields (yield/harvested acre) for the period 1983-1993 (USDA-NASS, 1983-1993). EPIC yields account for $78 \%$ of the variability in NASS yields for all crops considered. Wheat and soybean yields are estimated reasonably well by EPIC. Corn and sorghum yields are more frequently overestimated than underestimated. Overestimation is to be expected since EPIC assumes crop management at uniformly high levels of technology and harvest efficiency. No attempt has been made in these simulations to account for the effects of episodic climatic events such as severe frosts, hail and windstorms or for pest damage - all of which lower real agricultural yields. 


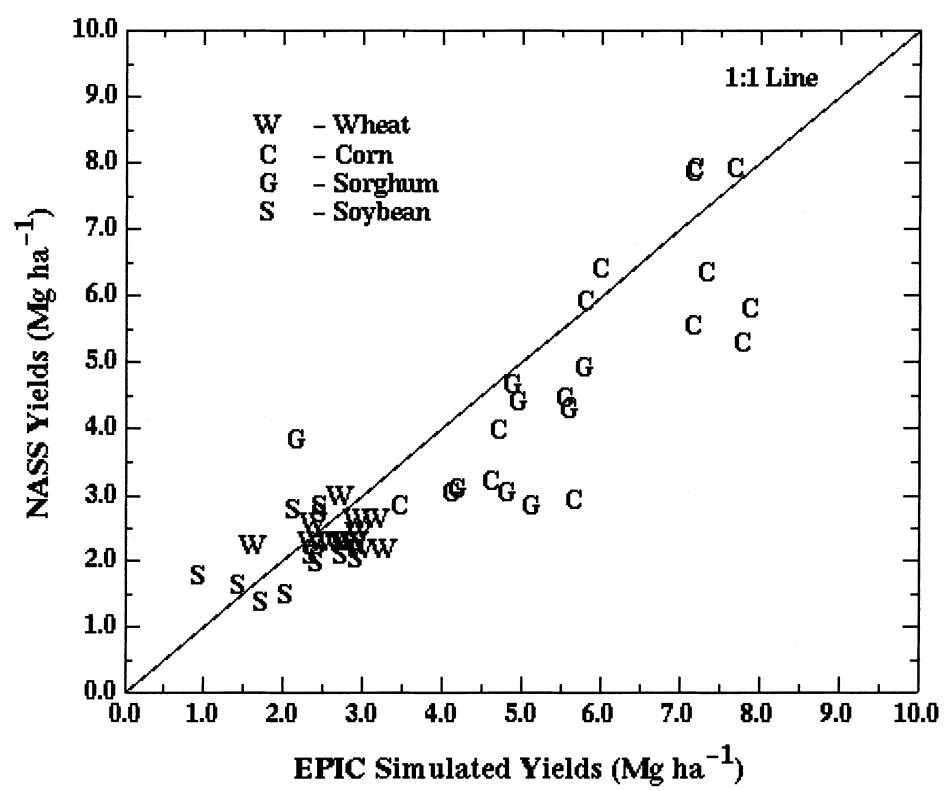

Fig. 2. EPIC-simulated yields compared with historic yields (from USDA-NASS county crops database) for grain crops on 13 representative farms in the MINK region.

\subsubsection{Switchgrass simulations}

Switchgrass has not been cultivated extensively in the MINK region. Thus, no long-term records of historic yields exist against which to validate the EPIC switchgrass results. Recent switchgrass yield trials conducted in the MINK region (Vogel, 1996a) present an opportunity for validation. Rosenberg et al. (1992) argue that EPIC, in any event, is best compared with experimental yields, since both utilize optimal management. Kiniry et al. (1996) compared switchgrass yields simulated by ALMANAC — a model similar to EPIC — with yields from agronomic trials in Texas and found that simulated yields explained $79 \%$ of the variability in measured yields.

Switchgrass simulations were compared against data from factorial experiments which tested the effects of nitrogen fertilization rates and harvest schedule on switchgrass yield between 1993 and 1995 at Ames, IA (42.00 $\mathrm{N}$ lat., $93.50 \mathrm{~W}$ long., $\approx 725 \mathrm{~mm}$ annual precipitation, soil series Webster) and Mead, $\mathrm{NE}$ (41.30 N lat., $96.60 \mathrm{~W}$ long., $\approx 675 \mathrm{~mm}$ annual precipitation, soil series Sharpsburg) (Vogel, 1996a). Switchgrass was planted in 1993 to establish the crop. Fertilization rates were varied from 0 to $300 \mathrm{~kg} \mathrm{ha}^{-1}$ of $\mathrm{N}$ in $60 \mathrm{~kg} \mathrm{ha}^{-1}$ increments, and the crop was harvested at weekly intervals from late June into September. A final harvest was made at the end of the growing season in November. EPIC datasets were constructed to approximate the environmental and agronomic conditions of the experiment and then used to model switchgrass production over a 30-year period, repeating the climate records of 1993-1995 and using simulated mean yields for comparison.

Table 2 compares the mean experimental and EPIC simulated yields for switchgrass at both sites. Mean experimental yields were calculated by averaging all data for 1994-1995. Experimental yields existed for both summer and fall cutting, allowing us to compare EPICs ability to match annual yield and to model switchgrass growth and development through the growing season. On average, EPIC underestimated the summer harvest and overestimated the fall harvest. Agreement was better for total yields. Fig. 3 compares the response of the observed and simulated yields to differing levels of $\mathrm{N}$ fertilization rates. Agreement between observed and simulated yields is excellent for the Ames, IA site up to the $\mathrm{N}$ application rate of $180 \mathrm{~kg} \mathrm{ha}^{-1}$. At greater rates the simulated yields continue to rise linearly while the experimental yields show a diminishing response. EPIC simulated yields 
Table 2

Mean yields, standard deviations and root mean square error (RMSE) for switchgrass experimental yields and EPIC simulated yields by location and harvest

\begin{tabular}{|c|c|c|c|c|c|c|}
\hline \multirow[t]{2}{*}{ Site } & & \multicolumn{2}{|c|}{ Measured yields $\left(\mathrm{Mgha}^{-1}\right)$} & \multicolumn{2}{|c|}{ Simulated yields $\left(\mathrm{Mg} \mathrm{ha}^{-1}\right)$} & \multirow[t]{2}{*}{$\mathrm{RMSE}^{\mathrm{b}}$} \\
\hline & & Mean & Stdev. ${ }^{\mathrm{a}}$ & Mean & Stdev. $^{\mathrm{a}}$ & \\
\hline Ames & Summer cutting & 9.9 & 2.4 & 9.1 & 1.8 & 2.6 \\
\hline Mead & & 9.3 & 1.9 & 7.5 & 2.2 & 2.9 \\
\hline Ames & Fall cutting & 1.9 & 0.6 & 3.7 & 0.9 & 2.0 \\
\hline Mead & & 1.5 & 0.4 & 2.4 & 0.6 & 1.0 \\
\hline Ames & Annual yield ${ }^{c}$ & 11.7 & 2.3 & 12.8 & 2.5 & 3.0 \\
\hline Mead & & 10.8 & 2.6 & 9.8 & 2.6 & 2.7 \\
\hline
\end{tabular}

a Standard deviation.

${ }^{\mathrm{b}}$ Root mean square error.

${ }^{c}$ Annual yield is calculated by summing yields from the summer and fall cutting.

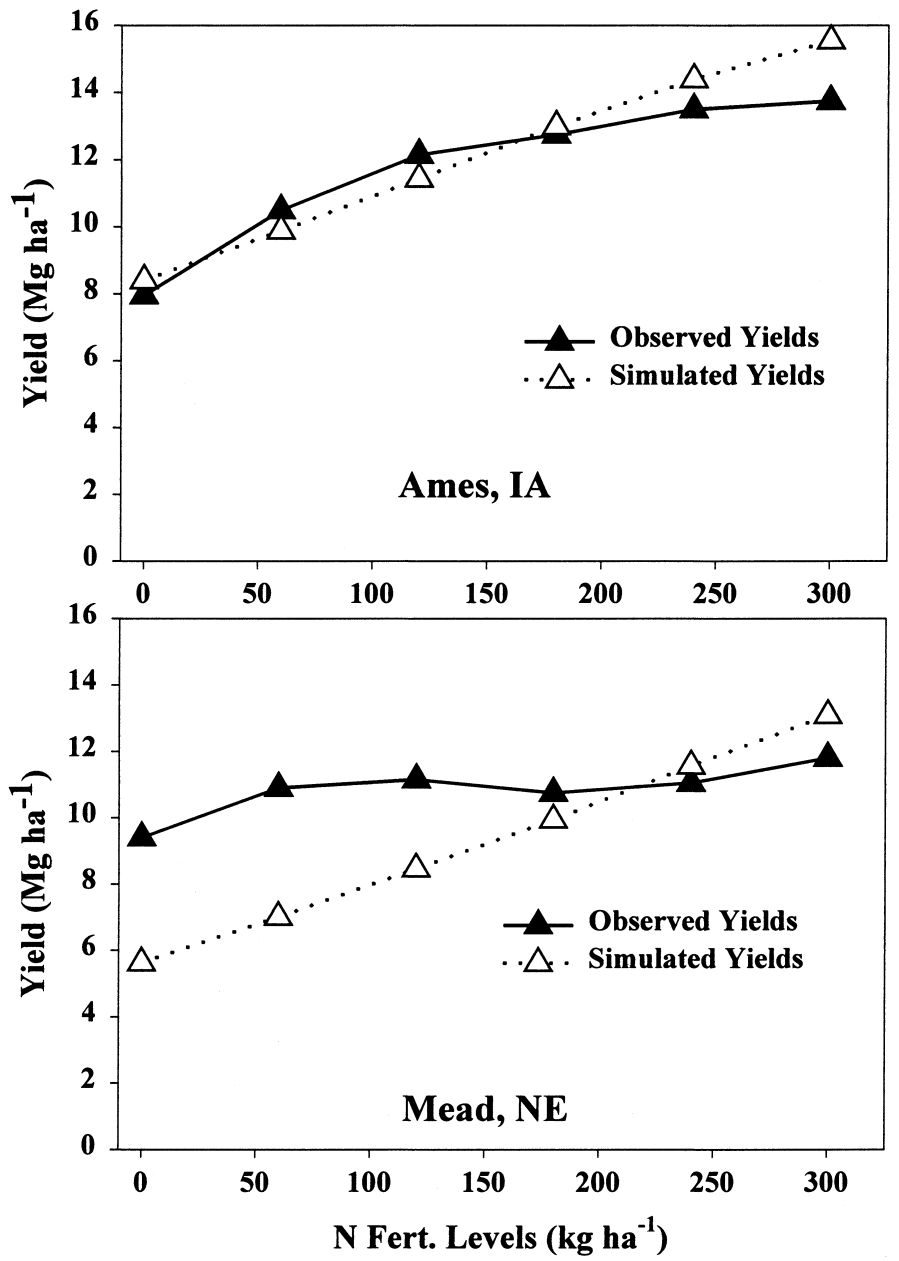

Fig. 3. Comparison of experimental and simulated switchgrass yield response to differing nitrogen fertilization rates at Ames, IA and Mead, NE. 
Table 3

Mean seasonal baseline temperatures, seasonal precipitation totals and deviations from baseline under the RegCM climate change scenario for eight representative farms within the MINK region

\begin{tabular}{|c|c|c|c|c|c|c|c|c|c|c|c|c|}
\hline \multirow[t]{2}{*}{ Farm \# ${ }^{\mathrm{a}}$} & \multicolumn{3}{|c|}{ Winter $(\mathrm{D}, \mathrm{J}, \mathrm{F})$} & \multicolumn{3}{|c|}{ Spring $(\mathrm{M}, \mathrm{A}, \mathrm{M})$} & \multicolumn{3}{|c|}{ Summer $(\mathrm{J}, \mathrm{J}, \mathrm{A})$} & \multicolumn{3}{|c|}{ Fall $(\mathrm{S}, \mathrm{O}, \mathrm{N})$} \\
\hline & Baseline & $\operatorname{RegCM}{ }^{b}$ & Change & Baseline & RegCM & Change & Baseline & $\operatorname{RegCM}$ & Change & Baseline & Regcm & Change \\
\hline \multicolumn{13}{|c|}{ Mean temperature $\left({ }^{\circ} \mathrm{C}\right)$} \\
\hline 1 & -6.7 & 0.1 & 6.8 & 8.7 & 16.2 & 7.5 & 21.5 & 26.2 & 4.6 & 9.0 & 13.8 & 4.8 \\
\hline 2 & -4.5 & 1.5 & 6.0 & 10.0 & 16.3 & 6.3 & 22.6 & 27.2 & 4.7 & 10.1 & 14.9 & 4.8 \\
\hline 3 & -2.4 & 2.7 & 5.1 & 11.2 & 16.8 & 5.6 & 23.5 & 28.4 & 4.9 & 11.6 & 16.2 & 4.6 \\
\hline 4 & 1.0 & 5.7 & 4.7 & 13.3 & 18.8 & 5.5 & 24.4 & 29.1 & 4.7 & 13.9 & 18.4 & 4.5 \\
\hline 5 & 0.0 & 4.2 & 4.3 & 12.9 & 18.0 & 5.1 & 24.8 & 29.4 & 4.6 & 13.5 & 18.1 & 4.6 \\
\hline 6 & -0.9 & 2.9 & 3.7 & 11.0 & 15.3 & 4.3 & 23.8 & 28.1 & 4.3 & 11.8 & 16.2 & 4.4 \\
\hline 7 & -3.5 & 1.5 & 5.0 & 10.2 & 15.8 & 5.6 & 23.2 & 27.6 & 4.5 & 10.3 & 15.1 & 4.8 \\
\hline 8 & -3.7 & 0.9 & 4.6 & 8.1 & 13.2 & 5.1 & 21.4 & 25.7 & 4.2 & 8.8 & 13.0 & 4.2 \\
\hline \multicolumn{13}{|c|}{ Total precipitation $(\mathrm{mm})$} \\
\hline 1 & 84 & 113 & 29 & 254 & 266 & 12 & 298 & 343 & 44 & 247 & 361 & 115 \\
\hline 2 & 56 & 67 & 11 & 271 & 311 & 40 & 299 & 316 & 18 & 186 & 273 & 87 \\
\hline 3 & 80 & 91 & 11 & 254 & 360 & 107 & 321 & 322 & 1 & 227 & 275 & 48 \\
\hline 4 & 168 & 196 & 28 & 305 & 359 & 54 & 286 & 314 & 28 & 304 & 400 & 96 \\
\hline 5 & 93 & 106 & 13 & 296 & 376 & 81 & 289 & 302 & 13 & 258 & 321 & 63 \\
\hline 6 & 48 & 49 & 2 & 208 & 330 & 122 & 217 & 269 & 52 & 96 & 115 & 19 \\
\hline 7 & 56 & 63 & 7 & 245 & 291 & 47 & 278 & 325 & 47 & 186 & 231 & 45 \\
\hline 8 & 31 & 38 & 7 & 139 & 218 & 79 & 215 & 246 & 30 & 80 & 93 & 13 \\
\hline
\end{tabular}

${ }^{a}$ Farm locations are identified in Fig. 1 and summarized in Table 1.

${ }^{b}$ NCAR RegCM2 model simulation of $2 \times \mathrm{CO}_{2}$ climate change scenario.

from the Mead, NE, site also show a linear increase to $\mathrm{N}$ fertilization; however, agreement with observed yields is poor, with the observed yields virtually unresponsive to fertilizer rates.

EPIC reasonably matches mean annual switchgrass yields from agronomic trials at two sites in the MINK region. The validation results are comparable with previous EPIC model validations (Rosenberg et al., 1992; Kiniry et al., 1996; Brown and Rosenberg, 1999). However, the results also show disagreement between observed and simulated data with regard to the effect of yield to $\mathrm{N}$ application rates. While these flaws are not severe enough to dismiss the modeling results, they do introduce a level of uncertainty and highlight areas where the model needs to be improved to correctly mimic switchgrass growth and development.

\subsection{Climate scenarios}

The climate scenarios used in this study are reported in full by Mearns et al. (1999a, 1999b). Seasonal means of temperature and precipitation for the baseline climate and deviations from baseline under the RegCM scenario are presented in Table 3. Mean winter temperatures range from $1.6^{\circ} \mathrm{C}$ in the south to $-8.8^{\circ} \mathrm{C}$ in the most northerly regions. Spring temperatures range from 13.8 to $5.8^{\circ} \mathrm{C}$; summer from 26.1 to $18.5^{\circ} \mathrm{C}$; fall from 14.4 to $6.6^{\circ} \mathrm{C}$. For fall and summer, the RegCM scenario increases temperatures from 4 to $5^{\circ} \mathrm{C}$ for the entire study region (summer, Fig. 4(b)). For winter and spring, the RegCM scenario raises temperature from 6 to $8^{\circ} \mathrm{C}$ in Iowa and northeastern Nebraska (farms 1-2) from southwest to northeast (winter, Fig. 4(a)). Giorgi et al. (1998) attribute these dramatic increases in the region's winter and spring temperatures to the loss of permanent snow cover, resulting in a snow albedo feedback.

The study region experiences increased precipitation under the RegCM scenario. Increases in winter (Fig. 4(c)) are modest ranging from 0 to $50 \mathrm{~mm}$, but as a percentage change comparable to the other seasons. Spring increases range from 0 to $200 \mathrm{~mm}$ with the largest increases concentrated in north central Missouri, south central Iowa and central Kansas. Changes in precipitation are more randomly distributed in summer than other seasons. Summer (Fig. 4(d)) increases range from 0 to $200 \mathrm{~mm}$, however, 
(a) Winter temperature deviations

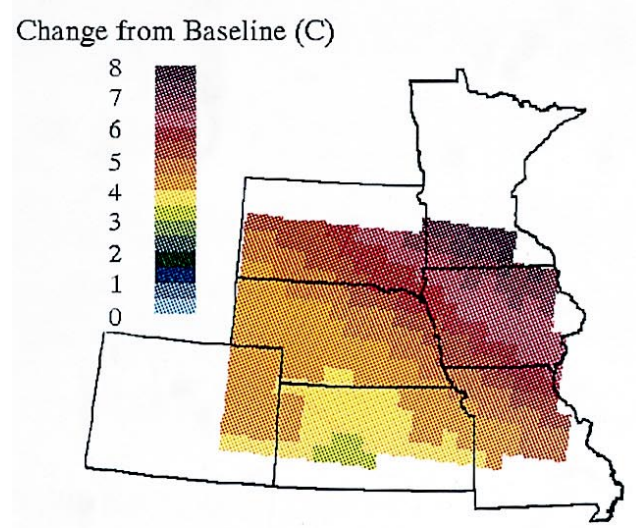

(c) Winter precipitation deviations

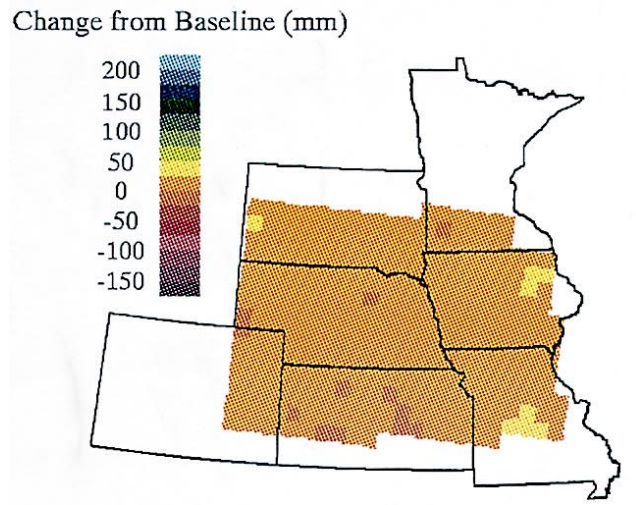

(b) Summer temperature deviations

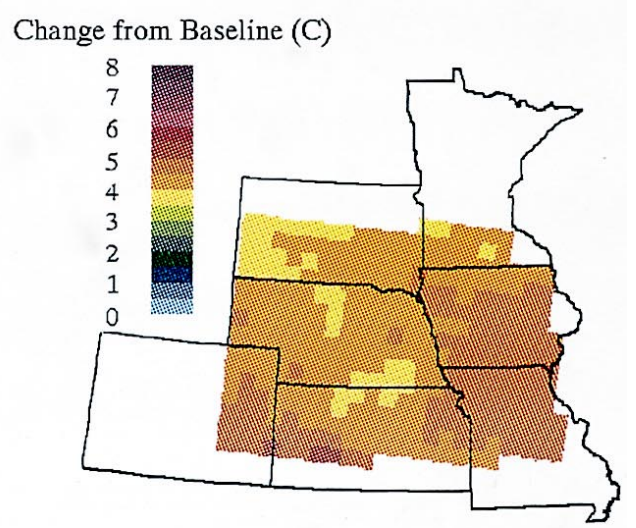

(d) Summer precipitation deviations

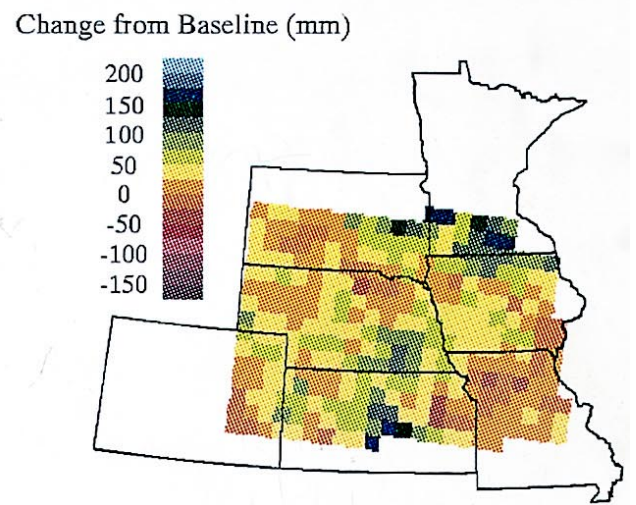

Fig. 4. Temperature and precipitation deviations from baseline under the RegCM climate change scenario for winter (December-January-February) and summer (June-July-August).

precipitation decreases in $12 \%$ of the grids. Deviations ranging up to $200 \mathrm{~mm}$ occur in fall, increasing in amount from west to east.

\subsection{Baseline and RegCM simulated yields}

\subsubsection{Traditional crops}

Table 4 summarizes yield results from the EPIC simulations and Table 5 presents EPIC recorded stress day data simulations for both the traditional crops and switchgrass under baseline and the RegCM climate change scenario. Table 6 presents simulated yields and stress data for eight representative farms (identified in Fig. 1 and described in Table 1) under corn, winter wheat and switchgrass cultivation.
Under baseline climate, simulated crop yields are highest in Iowa and Missouri with yields declining in western Nebraska and Kansas. The high corn and soybean yields in Iowa and Missouri coincide with minimal water and nutrient stress. The highest sorghum yields occurred in eastern Nebraska. Interestingly, sorghum yields in Iowa are reduced from the maximum due to cold temperature stress. Water stress decreases corn and soybean yields in central Nebraska and Kansas. Sorghum and winter wheat, which are relatively insensitive to precipitation shortages, maintain yields at levels approaching those on the eastern farms. Winter wheat yields showed reasonable potential in the western zone, exceeding $1.0 \mathrm{Mg} \mathrm{ha}^{-1}$ in some cases. 
Table 4

Simulated yield means, standard deviations and range for the 302 representative farms sorted by crop and climate scenario

\begin{tabular}{|c|c|c|c|c|c|c|c|c|c|}
\hline \multirow[t]{2}{*}{ Crop } & \multicolumn{3}{|c|}{ Baseline $\left(\mathrm{Mg} \mathrm{ha}^{-1}\right)$} & \multicolumn{3}{|c|}{$\operatorname{RegCM}^{\mathrm{a}}\left(\mathrm{Mgha}^{-1}\right)$} & \multicolumn{3}{|c|}{$\operatorname{RegCM}+\mathrm{CO}_{2}{ }^{\mathrm{b}}\left(\mathrm{Mgha}^{-1}\right)$} \\
\hline & Mean & Stdev. & Range & Mean & Stdev. & Range & Mean & Stdev. & Range \\
\hline Corn & 5.2 & 2.0 & $0.6-7.9$ & 5.3 & 1.3 & $0.4-7.2$ & 5.7 & 1.2 & $0.9-7.5$ \\
\hline Sorghum & 4.0 & 1.3 & $0.7-6.1$ & 3.9 & 1.1 & $0.8-5.5$ & 4.2 & 1.1 & $0.9-5.8$ \\
\hline Soybean & 1.8 & 0.7 & $0.4-3.0$ & 1.7 & 0.5 & $0.4-2.4$ & 2.0 & 0.5 & $0.6-2.9$ \\
\hline Winter wheat & 2.5 & 0.5 & $1.1-3.6$ & 2.5 & 0.4 & $1.6-3.8$ & 2.8 & 0.5 & $1.6-4.1$ \\
\hline Switchgrass & 6.8 & 1.9 & $2.2-12.0$ & 11.8 & 3.2 & $3.8-17.5$ & 13.4 & 3.6 & $4.0-19.7$ \\
\hline
\end{tabular}

a NCAR RegCM2 model simulation of $2 \times \mathrm{CO}_{2}$ climate change scenario with $\left[\mathrm{CO}_{2}\right]=365 \mathrm{ppm}$.

${ }^{\mathrm{b}} \mathrm{NCAR}$ RegCM2 model simulation of $2 \times \mathrm{CO}_{2}$ climate change scenario with $\left[\mathrm{CO}_{2}\right]=560 \mathrm{ppm}$.

Temperature increases under the RegCM climate decrease crop yields in the eastern and central portion of the study region. The higher temperatures induce a more rapid accumulation of heat units, speeding phenological development, shortening the growing season and reducing crop yields. Yield decreases ranged from 0.6 to $1.1 \mathrm{Mg} \mathrm{ha}^{-1}$ for corn, for sorghum from 0.2 to $0.6 \mathrm{Mgha}^{-1}$, for soybean from 0.1 to $0.6 \mathrm{Mg} \mathrm{ha}^{-1}$ in the eastern and central zones. In the case of winter wheat, yield decreases were associated with increases in water stress (e.g., farm 1). Increased temperatures reduced the frequency of cold temperature stress suffered by winter wheat, which benefited yields. A decrease in temperature stress is responsible for the increased yield of winter wheat on farm 3. This effect is also evident for sorghum and soybean in the northern zone (farms 1,2). In the case of corn, the higher temperatures, while no doubt decreasing cold stress, also increase heat stress, resulting in a net increase in temperature stress days. Precipitation increases benefited crop yields by reducing water stress. Yield response was most evident in western Nebraska and Kansas. Corn, soybean and sorghum are most sensitive with yields increasing above baseline levels (e.g., farms 6, 8 for corn; 6 for soybean).

Table 5

Simulated stress day mean, median and range for the 302 representative farms by crop and climate scenario

\begin{tabular}{|c|c|c|c|c|c|c|c|c|c|c|c|c|c|}
\hline \multirow[t]{2}{*}{ Crop } & \multirow[t]{2}{*}{ Scenario } & \multicolumn{3}{|c|}{ Water stress (days) } & \multicolumn{3}{|c|}{ Temperature stress (days) } & \multicolumn{3}{|c|}{ Nitrogen stress (days) } & \multicolumn{3}{|c|}{ Phosphorus stress (days) } \\
\hline & & Mean & Median & Range & Mean & Median & Range & Mean & Median & Range & Mean & Median & Range \\
\hline \multirow[t]{3}{*}{ Corn } & Baseline & 17 & 9 & $1-66$ & 15 & 14 & $4-62$ & 6 & 1 & $0-30$ & 2 & 0 & $0-22$ \\
\hline & $\operatorname{RegCM}^{\mathrm{a}}$ & 9 & 3 & $1-39$ & 19 & 17 & $6-37$ & 5 & 3 & $0-29$ & 2 & 1 & $0-22$ \\
\hline & $\mathrm{RegCM}+\mathrm{CO}_{2}{ }^{\mathrm{b}}$ & 6 & 2 & $1-35$ & 18 & 17 & $5-37$ & 8 & 8 & $0-36$ & 3 & 1 & $0-27$ \\
\hline \multirow[t]{3}{*}{ Sorghum } & Baseline & 17 & 12 & $1-56$ & 20 & 19 & $3-70$ & 3 & 0 & $0-31$ & 1 & 0 & $0-29$ \\
\hline & $\operatorname{RegCM}$ & 8 & 4 & $1-37$ & 14 & 14 & $3-34$ & 3 & 1 & $0-31$ & 1 & 0 & $0-24$ \\
\hline & $\operatorname{RegCM}+\mathrm{CO}_{2}$ & 5 & 2 & $1-34$ & 14 & 14 & $3-34$ & 4 & 3 & $0-36$ & 1 & 1 & $0-27$ \\
\hline \multirow[t]{3}{*}{ Soybean } & Baseline & 21 & 18 & $2-62$ & 18 & 16 & $4-66$ & 0 & 0 & $0-0$ & 2 & 0 & $0-24$ \\
\hline & $\operatorname{RegCM}$ & 9 & 6 & $1-37$ & 13 & 12 & $3-27$ & 0 & 0 & $0-0$ & 1 & 0 & $0-11$ \\
\hline & $\mathrm{RegCM}+\mathrm{CO}_{2}$ & 7 & 4 & $1-35$ & 13 & 12 & $4-27$ & 0 & 0 & $0-0$ & 2 & 1 & $0-22$ \\
\hline \multirow[t]{3}{*}{ Winter wheat } & Baseline & 31 & 27 & $9-78$ & 120 & 119 & 64-161 & 10 & 5 & $0-74$ & 2 & 0 & $0-33$ \\
\hline & RegCM & 26 & 26 & $5-73$ & 68 & 69 & $28-90$ & 19 & 17 & $0-75$ & 6 & 4 & $0-48$ \\
\hline & $\mathrm{RegCM}+\mathrm{CO}_{2}$ & 20 & 20 & $4-66$ & 79 & 81 & $40-105$ & 30 & 30 & $0-87$ & 7 & 5 & $0-59$ \\
\hline \multirow[t]{3}{*}{ Switchgrass } & Baseline & 30 & 28 & $1-75$ & 193 & 194 & $156-245$ & 37 & 41 & $0-70$ & 32 & 35 & $0-74$ \\
\hline & RegCM & 44 & 47 & 0-90 & 150 & 154 & $106-200$ & 2 & 0 & $0-66$ & 45 & 51 & $0-89$ \\
\hline & $\mathrm{RegCM}+\mathrm{CO}_{2}$ & 53 & 49 & $8-137$ & 148 & 152 & $104-200$ & 3 & 0 & $0-75$ & 70 & 76 & $1-108$ \\
\hline
\end{tabular}

${ }^{a} \mathrm{NCAR}$ RegCM2 simulation of $2 \times \mathrm{CO}_{2}$ climate change scenario with $\left[\mathrm{CO}_{2}\right]=365 \mathrm{ppm}$.

${ }^{\mathrm{b}} \mathrm{NCAR}$ RegCM2 simulation of $2 \times \mathrm{CO}_{2}$ climate change scenario with $\left[\mathrm{CO}_{2}\right]=560 \mathrm{ppm}$. 
Table 6

EPIC simulated mean yields, water stress days, temperature stress days and growing season under baseline climate, RegCM climate and RegCM climate with increased $\mathrm{CO}_{2}$ for eight representative farms under corn, winter wheat and switchgrass cultivation

\begin{tabular}{|c|c|c|c|c|c|c|c|c|c|c|c|c|}
\hline \multirow[t]{2}{*}{ Farm $\#^{\mathrm{a}}$} & \multicolumn{3}{|c|}{$\begin{array}{l}\text { Yield } \\
\left(\mathrm{Mgha}^{-1}\right)\end{array}$} & \multicolumn{3}{|c|}{$\begin{array}{l}\text { Water stress } \\
\text { (days) }\end{array}$} & \multicolumn{3}{|c|}{$\begin{array}{l}\text { Temperature } \\
\text { stress (days) }\end{array}$} & \multicolumn{3}{|c|}{$\begin{array}{l}\text { Growing } \\
\text { season (days) }\end{array}$} \\
\hline & Baseline & $\begin{array}{l}\operatorname{RegCM}^{b} \\
\operatorname{RegCM}^{b}\end{array}$ & $\begin{array}{l}\mathrm{RegCM}+ \\
\mathrm{CO}_{2}{ }^{\mathrm{c}}\end{array}$ & Baseline & RegCM & $\begin{array}{l}\mathrm{RegCM}+ \\
\mathrm{CO}_{2}\end{array}$ & Baseline & RegCM & $\begin{array}{l}\mathrm{RegCM}+ \\
\mathrm{CO}_{2}\end{array}$ & Baseline & RegCM & $\begin{array}{l}\operatorname{RegCM}+ \\
\mathrm{CO}_{2}\end{array}$ \\
\hline \multicolumn{13}{|l|}{ Corn } \\
\hline 1 & 7.2 & 6.3 & 6.7 & 3 & 3 & 2 & 21 & 19 & 18 & 137 & 118 & 118 \\
\hline 2 & 7.7 & 6.6 & 7.0 & 6 & 1 & 1 & 12 & 20 & 20 & 139 & 121 & 121 \\
\hline 3 & 7.9 & 6.9 & 7.4 & 5 & 2 & 1 & 13 & 18 & 18 & 155 & 126 & 126 \\
\hline 4 & 7.8 & 7.2 & 7.5 & 1 & 1 & 1 & 8 & 13 & 11 & 155 & 128 & 128 \\
\hline 5 & 5.8 & 5.2 & 5.3 & 3 & 1 & 1 & 6 & 8 & 7 & 158 & 126 & 126 \\
\hline 6 & 4.6 & 4.7 & 4.8 & 17 & 3 & 1 & 13 & 10 & 9 & 169 & 132 & 132 \\
\hline 7 & 6.0 & 5.8 & 6.0 & 3 & 1 & 1 & 10 & 16 & 16 & 162 & 128 & 128 \\
\hline 8 & 3.5 & 3.7 & 4.1 & 36 & 22 & 15 & 30 & 31 & 31 & 138 & 127 & 127 \\
\hline \multicolumn{13}{|c|}{ Winter wheat } \\
\hline 1 & 3.0 & 2.5 & 2.9 & 26 & 33 & 33 & 144 & 76 & 84 & 268 & 230 & 230 \\
\hline 2 & 2.9 & 2.9 & 3.4 & 28 & 25 & 24 & 131 & 74 & 82 & 262 & 230 & 230 \\
\hline 3 & 3.0 & 3.2 & 3.5 & 26 & 15 & 15 & 112 & 71 & 73 & 245 & 216 & 216 \\
\hline 4 & 3.2 & 2.9 & 3.1 & 14 & 7 & 6 & 84 & 54 & 52 & 233 & 204 & 204 \\
\hline 5 & 2.7 & 2.7 & 2.8 & 13 & 6 & 5 & 96 & 65 & 63 & 251 & 224 & 224 \\
\hline 6 & 2.4 & 2.4 & 2.5 & 26 & 14 & 11 & 110 & 79 & 77 & 259 & 235 & 235 \\
\hline 7 & 2.8 & 2.8 & 2.9 & 24 & 22 & 17 & 129 & 67 & 86 & 277 & 249 & 249 \\
\hline 8 & 1.6 & 1.7 & 1.7 & 35 & 39 & 35 & 129 & 68 & 89 & 287 & 258 & 258 \\
\hline \multicolumn{13}{|c|}{ Switchgrass } \\
\hline 1 & 6.2 & 15.9 & 17.7 & 4 & 21 & 13 & 203 & 159 & 158 & 81 & 112 & 112 \\
\hline 2 & 9.0 & 16.2 & 18.8 & 10 & 43 & 28 & 191 & 153 & 152 & 94 & 111 & 111 \\
\hline 3 & 8.8 & 15.8 & 18.0 & 17 & 48 & 37 & 183 & 139 & 138 & 99 & 110 & 110 \\
\hline 4 & 10.8 & 15.4 & 18.0 & 19 & 49 & 36 & 160 & 114 & 114 & 108 & 118 & 118 \\
\hline 5 & 9.4 & 13.0 & 15.2 & 31 & 59 & 45 & 166 & 123 & 123 & 103 & 117 & 117 \\
\hline 6 & 6.3 & 10.3 & 11.2 & 51 & 89 & 70 & 181 & 137 & 137 & 99 & 108 & 108 \\
\hline 7 & 6.8 & 13.0 & 15.1 & 24 & 52 & 40 & 191 & 146 & 145 & 99 & 112 & 112 \\
\hline 8 & 4.3 & 8.7 & 9.6 & 37 & 69 & 59 & 212 & 170 & 168 & 80 & 109 & 109 \\
\hline
\end{tabular}

${ }^{a}$ Farm locations are identified in Fig. 1 and summarized in Table 1.

${ }^{b} \mathrm{NCAR}$ RegCM2 simulation of $2 \times \mathrm{CO}_{2}$ climate change scenario with $\left[\mathrm{CO}_{2}\right]=365 \mathrm{ppm}$.

${ }^{\mathrm{c}} \mathrm{NCAR}$ RegCM2 simulation of $2 \times \mathrm{CO}_{2}$ climate change scenario with $\left[\mathrm{CO}_{2}\right]=560 \mathrm{ppm}$.

A pattern develops in which yields improve in the western and northern portions of the study region while those in the southern and eastern portions decline. This pattern is most evident in corn (Fig. 5(a)), soybean (Fig. 5(b)) and sorghum (not shown). For the study region, yield increases and decreases tend to cancel one another and regional mean yields of the traditional crops are not greatly affected (Table 4). These results for corn, wheat and soybean are comparable to those of Mearns et al. (1999b).

\subsubsection{Switchgrass}

Since switchgrass is a perennial forage crop, direct comparison of yields, growing season length and stress day frequencies with those of the grain crops can be misleading. Switchgrass yields differ from grain yields since all of its aboveground biomass is harvested. Stress days are more frequent for switchgrass since its growing season includes the period after summer harvest until dormancy.

Under baseline climate, simulated switchgrass yields range from 2.2 to $12.0 \mathrm{Mg} \mathrm{ha}^{-1}$ across the study 
(a) Corn yield deviations

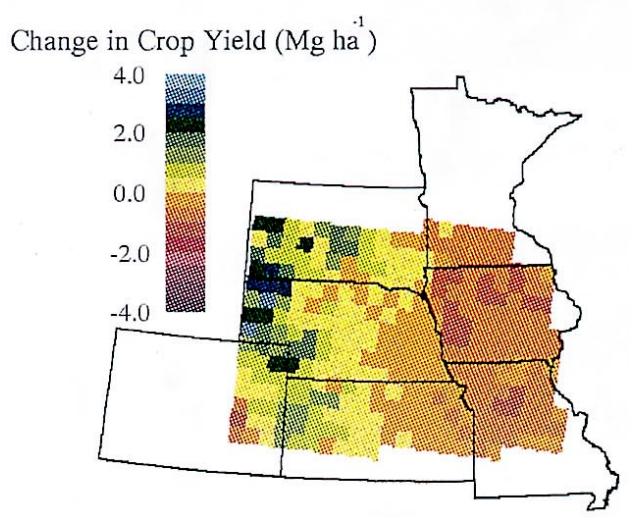

(c) Winter wheat yield deviations

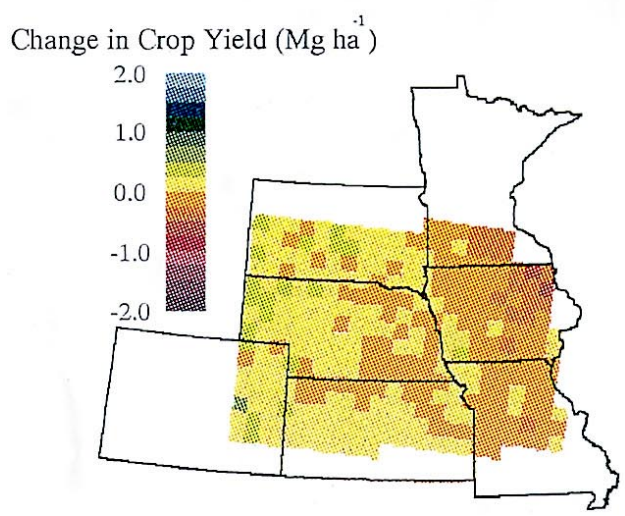

(b) Soybean yield deviations

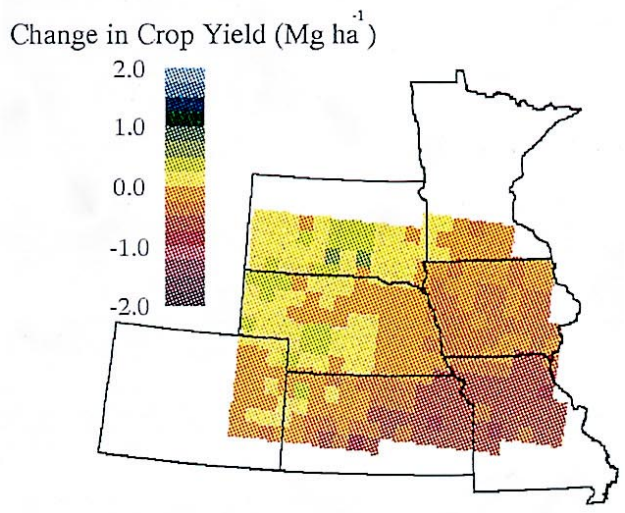

(d) Switchgrass yield deviations

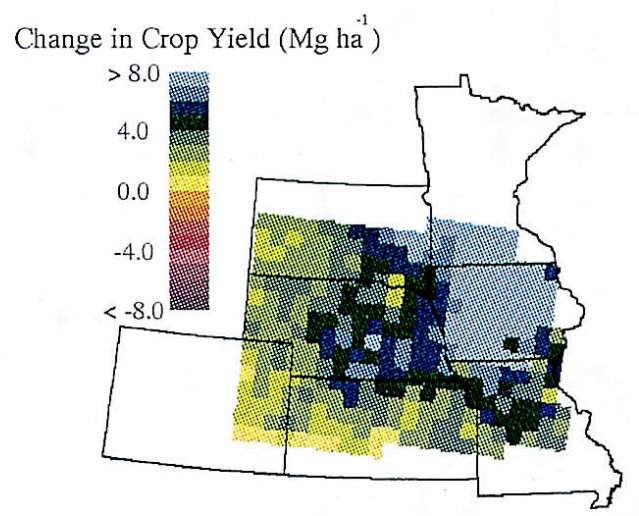

Fig. 5. Yield deviations from baseline for corn, soybean, winter wheat and switchgrass under the RegCM climate scenario with $\left[\mathrm{CO}_{2}\right]=365 \mathrm{ppm}$.

region with the highest yields in southern Kansas and Missouri and the lowest in western Nebraska. Low temperatures stress switchgrass and limit the growing season in the entire study region. Temperature stress in the northern zone exceeds 200 days in some cases (winter days are included in this number). Nitrogen stress also limits switchgrass yields and is primarily recorded during spring emergence. Water stress was evident in the western zone where yields ranged from 4.0 to $6.0 \mathrm{Mg} \mathrm{ha}^{-1}$. However, as compared to corn, switchgrass yields were insensitive to water shortages.

Notably, switchgrass yields (Fig. 5(d)) were favored by the RegCM climate change scenario with yields increasing from baseline on all 302 representative farms. Increases exceeding $8.0 \mathrm{Mg} \mathrm{ha}^{-1}$ are simulated in Iowa and eastern Nebraska. Switchgrass benefits from temperature increases of 6.0 to $8.0^{\circ} \mathrm{C}$ which reduce cold temperature stress and lengthen the growing season. Yield increases of 2.0 to $5.0 \mathrm{Mg} \mathrm{ha}^{-1}$ prevail in the western and central portions of Kansas and Nebraska. The lesser yield increases are associated with more modest increases in spring and winter temperatures and an increased frequency of water stress. This occurs despite increased precipitation and is most evident in southern Kansas.

Nutrient stress is virtually eliminated on all farms under switchgrass cultivation as the higher soil temperatures speed nitrate formation and increase crop available N. This effect is most important in late winter/early spring when switchgrass is emerging from dormancy. Since EPIC calculates N demand from crop biomass, switchgrass consumes the extra $\mathrm{N}$ available 
for crop uptake. Thus, volatilization and denitrification rates do not increase appreciably. This differs from the traditional summer crops that are planted after $\mathrm{N}$ becomes available in early spring.

\subsection{Simulated evapotranspiration, runoff and soil erosion}

Table 7 presents data on simulated water use and soil erosion under corn, winter wheat and switchgrass cultivation for baseline and the RegCM climate change for the eight representative farms identified in Fig. 1. Under baseline climate, the wheat crop ET is lowest, ranging from 372 to $644 \mathrm{~mm}$ while switch- grass ET is greatest ranging from 414 to $901 \mathrm{~mm}$. The high switchgrass ET rates are due to the crop's longer growing season and ability to extend roots deeper into the soil profile, both factors which are included in EPICs water use algorithms. Water use increases for all crops under the RegCM climate with switchgrass ET increasing significantly and ET of the traditional crops more moderately (Table 7). ET increases are due both to higher temperatures which raise evaporative demand and the greater precipitation, which increases water supply. The dramatic increases for switchgrass ET is due to the multiplicative effects of a lengthened growing season and increased plant biomass.

Table 7

EPIC simulated annual mean evapotranspiration, surface runoff and erosion under baseline climate, RegCM climate and RegCM climate with increased $\mathrm{CO}_{2}$ for eight representative farms under corn, winter wheat and switchgrass cultivation

\begin{tabular}{|c|c|c|c|c|c|c|c|c|c|}
\hline \multirow[t]{2}{*}{ Farm $\#^{a}$} & \multicolumn{3}{|c|}{ Evapotranspiration (ET) $\left(\mathrm{mm}\right.$ year $\left.^{-1}\right)$} & \multicolumn{3}{|c|}{ Surface runoff $(\mathrm{Q})\left(\mathrm{mm}\right.$ year $\left.^{-1}\right)$} & \multicolumn{3}{|c|}{ Soil erosion ${ }^{\mathrm{d}}\left(\mathrm{Mg} \mathrm{ha}^{-1}\right.$ year $\left.^{-1}\right)$} \\
\hline & Baseline & $\operatorname{RegCM}{ }^{b}$ & $\operatorname{RegCM}+\mathrm{CO}_{2}{ }^{\mathrm{c}}$ & Baseline & RegCM & $\mathrm{RegCM}+\mathrm{CO}_{2}$ & Baseline & RegCM & $\mathrm{RegCM}+\mathrm{CO}_{2}$ \\
\hline \multicolumn{10}{|l|}{ Corn } \\
\hline 1 & 533 & 578 & 545 & 1 & 12 & 14 & 21 & 53 & 50 \\
\hline 2 & 618 & 655 & 617 & 32 & 82 & 90 & 19 & 38 & 38 \\
\hline 3 & 627 & 658 & 617 & 12 & 35 & 36 & 10 & 21 & 20 \\
\hline 4 & 736 & 767 & 726 & 19 & 64 & 66 & 5 & 13 & 13 \\
\hline 5 & 682 & 693 & 659 & 73 & 155 & 160 & 58 & 123 & 124 \\
\hline 6 & 558 & 659 & 621 & 5 & 18 & 20 & 159 & 170 & 168 \\
\hline 7 & 599 & 630 & 589 & 7 & 25 & 26 & 26 & 39 & 37 \\
\hline 8 & 394 & 437 & 428 & 2 & 15 & 16 & 422 & 305 & 305 \\
\hline \multicolumn{10}{|c|}{ Winter wheat } \\
\hline 1 & 494 & 535 & 508 & 1 & 15 & 15 & 9 & 5 & 5 \\
\hline 2 & 542 & 597 & 568 & 39 & 93 & 96 & 2 & 2 & 2 \\
\hline 3 & 538 & 598 & 561 & 14 & 35 & 36 & 2 & 1 & 1 \\
\hline 4 & 644 & 712 & 671 & 24 & 64 & 65 & 0 & 1 & 1 \\
\hline 5 & 636 & 728 & 677 & 79 & 159 & 167 & 8 & 16 & 14 \\
\hline 6 & 514 & 624 & 578 & 9 & 21 & 22 & 29 & 18 & 16 \\
\hline 7 & 531 & 632 & 583 & 10 & 27 & 28 & 4 & 5 & 4 \\
\hline 8 & 372 & 414 & 386 & 4 & 18 & 18 & 33 & 28 & 28 \\
\hline \multicolumn{10}{|c|}{ Switchgrass } \\
\hline 1 & 627 & 874 & 825 & 1 & 12 & 13 & 28 & 17 & 17 \\
\hline 2 & 719 & 865 & 851 & 27 & 68 & 72 & 11 & 12 & 12 \\
\hline 3 & 758 & 927 & 908 & 12 & 34 & 35 & 1 & 1 & 1 \\
\hline 4 & 901 & 1034 & 1018 & 20 & 57 & 59 & 0 & 1 & 1 \\
\hline 5 & 802 & 935 & 925 & 66 & 122 & 129 & 1 & 4 & 4 \\
\hline 6 & 561 & 694 & 693 & 4 & 14 & 15 & 28 & 5 & 5 \\
\hline 7 & 666 & 817 & 804 & 7 & 19 & 21 & 13 & 11 & 10 \\
\hline 8 & 414 & 509 & 503 & 2 & 13 & 14 & 43 & 47 & 47 \\
\hline
\end{tabular}

${ }^{a}$ Farm locations are identified in Fig. 1 and summarized in Table 1.

b NCAR RegCM2 simulation of $2 \times \mathrm{CO}_{2}$ climate change scenario with $\left[\mathrm{CO}_{2}\right]=365 \mathrm{ppm}$.

${ }^{\mathrm{c}} \mathrm{NCAR}$ RegCM2 simulation of $2 \times \mathrm{CO}_{2}$ climate change scenario with $\left[\mathrm{CO}_{2}\right]=560 \mathrm{ppm}$.

${ }^{\mathrm{d}}$ Soil erosion data includes both simulated wind and water erosion estimates. 
Simulated annual runoff was lower under switchgrass cultivation than under the traditional crops. Under baseline climate, for example, runoff on Farm 5 in Kansas ranged from $79 \mathrm{~mm}$ under winter wheat to $66 \mathrm{~mm}$ under switchgrass cultivation. Low baseline precipitation limits runoff in the western zone regardless of crop cover. Greater precipitation under the RegCM climate change increases runoff. Farms growing corn and wheat show more sensitivity to the changed climate than farms growing switchgrass. Increases from baseline runoff ranged from 11 to $82 \mathrm{~mm}$ with corn, from 13 to $80 \mathrm{~mm}$ with wheat and from 10 to $56 \mathrm{~mm}$ with switchgrass as cover. While the greatest absolute increases in runoff occurred on farms in the eastern and central zone of the study region, the relative changes in the western zone are also notable.

EPIC-simulated rates of erosion are generally highest on farms growing corn due to more frequent tillage of this crop. The high rates of erosion on corn farms 6 and 8 are due to steep topography. At these sites, cultivation of winter wheat and switchgrass reduces erosion significantly. Annual average erosion on farm 1 is slightly greater under switchgrass cultivation $\left(28 \mathrm{Mg} \mathrm{ha}^{-1}\right)$ than under corn or wheat cultivation. This higher value is an artifact explained by the incidence of strong wind erosion during the establishment of the switchgrass in the first year of its 10 -year rotation. More than $95 \%$ of all the erosion occurs in that year. Ranney and Mann (1994) present experimental data showing similar erosion results. They conclude that most erosion in short rotation woody crops grown for biomass occurs during the establishment period and suggest that proper management of crop residues can mitigate much of this erosion.

The pattern of simulated erosion rates under the RegCM scenario differs by crop. In general, erosion under switchgrass cultivation decreases, it increases under corn and remains insensitive under winter wheat cultivation (Table 7). The higher erosion rates for corn are due to the increased precipitation and runoff which prevail under the RegCM climate. The increased growth for switchgrass reduces the erosion risk by providing a continuous cover throughout the year. These results are similar to those of Phillips et al. (1993) where increases in storm frequency and intensity under a set of GCM climate change scenarios increased the national potential erosion amounts on cropland by $2-16 \%$.

\subsection{The $\mathrm{CO}_{2}$-fertilization effect}

The effects of the RegCM climate change scenario on EPIC-simulated yields are modified when the simulations reported above were repeated with $\left[\mathrm{CO}_{2}\right]=560 \mathrm{ppm}$. Tables 4-6 present simulated yield and stress day data and Table 7 presents simulated water use and soil erosion data RegCM climate change with increased $\mathrm{CO}_{2}$.

For all crops, increased $\left[\mathrm{CO}_{2}\right]$ decreases water stress in the central and western zones (farms 6,8) where water supply is inadequate even under the climate change scenario. Corn and sorghum yields are most responsive to decreased water stress, while winter wheat is least affected. Elevated $\left[\mathrm{CO}_{2}\right]$ does not affect temperature stress. $\mathrm{N}$ stress, on the other hand, is increased by elevated $\left[\mathrm{CO}_{2}\right]$ in all crops but soybean. Increases in $\mathrm{N}$ stress are due to increased production of biomass which increases crop demand for it.

Relative yield increases under $\mathrm{CO}_{2}$-fertilization are greatest for soybean and winter wheat, C3 crops which benefit from increased water use efficiency and greater photosynthetic efficiency. Yield gains for winter wheat are greatest in Iowa and Missouri with maximum increases from baseline of $0.5 \mathrm{Mg} \mathrm{ha}^{-1}$. Elevated $\left[\mathrm{CO}_{2}\right]$ raised yields only slightly on wheat farms in central and western Kansas and Nebraska (farms 6, 8). However, these increases were large enough to return yields to or above baseline. For corn and sorghum, relative yield increases are smaller than in soybean and winter wheat and inversely correlated with water stress. EPIC is programmed to simulate only small responses in photosynthetic efficiency for $\mathrm{C} 4$ crops.

Switchgrass increases yields up to $2.6 \mathrm{Mgha}^{-1}$ above those under climate change alone. As with the other $\mathrm{C} 4$ crops, the yield increases at higher $\left[\mathrm{CO}_{2}\right]$ are explained by improved water use efficiency. Switchgrass is the only crop in which the simulations show increased $\mathrm{P}$ stress under elevated $\left[\mathrm{CO}_{2}\right]$ - by as many as 38 days more than baseline on farm 8. Increased $\mathrm{P}$ stress is explained by two factors: the rapid growth rate of switchgrass may exhaust crop available $\mathrm{P}$ and the diminished number of temperature, water and $\mathrm{N}$ stress days allows $\mathrm{P}$ stress to register even if the severity of that stress does not change appreciably. 
This is an artifact of EPIC which allots a stress day to only that stress which is most severe on that day. That yields, the true measure of how well a plant adapts and grows in a given environment, increase despite the high number of $\mathrm{P}$ stress days supports this interpretation.

Since the $\mathrm{CO}_{2}$-fertilization effect increases water use efficiency, crop ET is decreased in all cases under the RegCM climate when $\left[\mathrm{CO}_{2}\right]=560 \mathrm{ppm}$. The greatest decreases in switchgrass ET occur in northeastern Iowa (farms 1, 2, 3), while corn and wheat ET decreases across the entire study region. Climate change with elevated $\left[\mathrm{CO}_{2}\right]$ increases runoff slightly regardless of crop cover while elevated $\left[\mathrm{CO}_{2}\right]$ has minimal impact on soil erosion with small changes evident for all crops.

\section{Discussion}

In general, temperature increases under the RegCM climate are most important in determining yield response for both the traditional crops and switchgrass. Temperature increases lowered yields of the traditional crops, while improving those of switchgrass. Higher temperatures speed maturity of the grain crops which, all else equal, decreases yields. This finding is consistent with results obtained by Easterling et al. (1992), Rosenzweig et al. (1994), Brown and Rosenberg (1999) and Mearns et al. (1999a) which also show the negative impact of rising temperatures and shortened growing season on grain yields. The increases in precipitation benefited crop yields, but only slightly. Yields of corn, soybean and sorghum increased above baseline levels in western Kansas and Nebraska. It is unclear whether such yield increases would be sufficient to permit dryland production in the western MINK region. Such a question can be answered only by linking these results to an integrated economics and human activities modeling effort.

The simulation results presented with regard to changes in water use, runoff and soil erosion apply to the individual sites and depend on the specific soil, climate and management regime used. However, the results do show that large-scale conversion to switchgrass in the MINK region may affect water resources through decreased surface runoff. To fully address the potential implications of climate change and biomass energy crops for the region's water resources will require integration of the farm level results with a regional hydrologic assessment of impacts on water quality and quantity.

Past analyses have addressed or commented on the tradeoffs among biomass energy production, traditional energy sources and agriculture (Lowenberg-DeBoer and Cherney, 1989; Reese et al., 1993; Vogel, 1996b) but have not considered the implications of greenhouse-forced climate change on biomass production. Other analyses have examined the impact of climate change on agriculture in the US Midwest using crop growth simulation models (Rosenzweig, 1989; Rosenberg, 1993; Rosenzweig et al., 1994; Brown and Rosenberg, 1997). Certain of these assessments consider farm level adaptations to climate change, but biomass cropping has not been among the adaptations considered. This simulation exercise has compared the yield response of switchgrass with those of corn, soybeans, sorghum and wheat to changes in climate and concluded that switchgrass can not only compete, in agronomic terms, with traditional crops under baseline climate, but will have a comparative advantage over these crops in a warmer climate. These findings here are consistent with those of an earlier study (Brown and Rosenberg, 1996) and taken together lead us to conclude that switchgrass could be the basis of a biomass energy industry in the MINK region. These findings also demonstrate the possible usefulness of switchgrass, a species native to the Great Plains, as an option for agricultural adaptation to climate change. Further, it will be easier for farmers to adopt switchgrass rather than woody species for biomass production since the same farm machinery and equipment as is used for grain production in the region can be employed. This analysis addresses only the potential production of switchgrass at the farm level. A full economic analysis of the crop's potential that considers production costs, transportation costs and market demand is needed before the practicality of a switchgrass agriculture for the MINK region can be established

\section{Conclusions}

Finding presented in this paper point to the following conclusions: 
1. Switchgrass yields are comparable, in agronomic terms, with yields of traditional annual grain crops under the current climate of the MINK region.

2. Under the RegCM climate change scenario employed here and characterized by increases in both temperature and precipitation, switchgrass yields increase over baseline levels for the entire MINK region. Yields of the traditional agricultural crops generally decrease in the eastern and southern portions of the region because of higher temperatures. Increases in precipitation in the western and central Great Plains improve yields of both switchgrass and the traditional crops over baseline and may, should they actually occur, increase this region's ability to sustain dryland agriculture.

3. Increases in atmospheric $\mathrm{CO}_{2}$ increase yields for all crops with soybean and winter wheat exhibiting the greatest response due to improvements in photosynthetic and water use efficiency. Because of improved water use efficiency, the $\mathrm{C} 4$ crops corn, switchgrass and sorghum - are more responsive to increased atmospheric $\mathrm{CO}_{2}$ in the water scarce regions.

4. Switchgrass generally consumes more water than do the traditional crops under all climate conditions and also reduces runoff. Soil erosion rates under switchgrass cultivation are comparable to those under winter wheat and are generally lower than those under corn cultivation.

5. Simulated switchgrass yields for the MINK region were sufficiently good under both baseline and the RegCM climate change to suggest its promise as a biomass energy feedstock. Because switchgrass thrives in warmer temperatures, the crop may serve as an agricultural adaptation to climate change as well.

\section{Acknowledgements}

This study was supported by the Great Plains Regional Center, a component of the National Center for Global Environmental Change (NIGEC), US under Department of Energy Contract 62-123-6512. We thank Cesar Izaurralde and Elizabeth Malone of PNNL and Paul Dyke, John Ellis, Jimmy Williams, Jim Kiniry, Georgie Mitchell, Verel Benson and Raghavan Srinivasan of the Blacklands Research
Center Temple, Texas A \& M University for technical advice and modeling support. Dr. Ken Vogel of the University of Nebraska-Lincoln Agronomy Department provided the switchgrass experimental data used in model validation. Dr. Robert Ahrens of the National Soil Survey Center assisted us with soil classification and taxonomy. Suzette Hampton provided stenographic assistance. We also thank the reviewers for their helpful comments and suggestions.

\section{References}

Anderson, B., 1989. Establishing Dryland Forage Grasses. NebGuide G81-543. Coop. Extension, Institute of Agriculture and Natural Resources, Univ. of Nebraska, Lincoln, Nebraska.

Anderson, B., Shapiro, C.A., 1990. Fertilizing grass pastures and haylands. NebGuide G78-406. Coop. Extension, Institute of Agriculture and Natural Resources, Univ. of Nebraska, Lincoln, Nebraska.

Brown, R.A., Rosenberg, N.J., 1999. Climate change impacts on the potential productivity of corn and winter wheat in their primary growing regions. Clim.Change 41, 73-107.

Brown, R.A., Rosenberg, N.J., Easterling, W.E., Hays, C.J., 1998. Potential production of switchgrass and traditional crops under current and greenhouse-altered climate in the 'MINK' region of the central United States. Rep. No. PNWD-2432, Pacific Northwest National Laboratory, Washington, DC.

Brown, R.A., Rosenberg, N.J., 1997. Sensitivity of crop yield and water use to change in a range of climatic factors and $\mathrm{CO}_{2}$ concentrations: a simulation study applying EPIC to the central United States. Agric. For. Meteorology 83, 171-203.

Brown, R.A., Rosenberg, N.J., 1996. The potential for biomass energy production in the Missouri-Iowa-Nebraska-Kansas (MINK) region. In: Proc. of the 1995 Society of American Foresters Convention, Society of American Foresters, Bethesda, MD, pp. 204-209.

Easterling, W.E., Weiss, A., Hays, C.J., Mearns, L.O., 1998. Optimum spatial scales of climate information for simulating the effects of climate change on agrosystem productivity: the case of the US Great Plains. Agric. For. Meteorology 90, 51-63.

Easterling, W.E., Rosenberg, N.J., McKenney, M.S., Jones, C.A., Dyke, P.T., Williams, J.R., 1992. Preparing the erosion productivity impact calculator (EPIC) model to simulate crop response to climate change and the direct effects of $\mathrm{CO}_{2}$. In: Rosenberg, N.J (Ed.), A Methodology for Assessing Regional Agricultural Consequences of Climate Change: Application to the Missouri-Iowa-Nebraska-Kansas (MINK) Region. Agric. and For. Meteorology 59, 17-34.

Giampietro, M., Ulgiatti, S., Pimentel, D., 1997. Feasibility of large-scale biofuel production. Bioscience 47, 587-600.

Giorgi, F., Mearns, L.O., Shields, C., McDaniel, L., 1998. Regional nested model simulations of present day and $2 \times \mathrm{CO}_{2}$ climate over the central plains of the US. Clim. Change 40, 457-493. 
Graham, R.L., Downing, M., Walsh, M.F., 1996. A framework to assess regional environmental impacts of dedicated energy crop production. Environ. Manage. 20, 475-485.

Graham, R.L., Wright, L.L., Turhollow, A.F., 1992. The potential for short-rotation woody crops to reduce US $\mathrm{CO}_{2}$ emissions. Clim. Change 22, 223-238.

Hall, D.O., 1997. Biomass energy in industrialized countries - a view of the future. For. Ecol. and Manage. 91, 17-45.

Hall, D.O., Mynick, H.E., Williams, R.H., 1993. Cooling the greenhouse with bioenergy. Nature 353, 11-12.

Hall, D.O., Mynick, H.E., Williams, R.H., 1990. Carbon sequestration versus fossil fuel substitution: alternative roles for biomass in coping with greenhouse warming. Rep. No. 255. Center for Energy and Environmental Studies, Princeton University, New Jersey.

Kiniry, J.R., Sanderson, M.A., Williams, J.R., Tischler, C.R., Hussey, M.A., Ocumpaugh, W.R., Read, J.C., Van Esbroeck, G., Read, R.L., 1996. Simulating Alamo switchgrass with the ALMANAC model. Agron. J. 88, 602-606.

Kiniry, J.R., Spanel, D.A., Williams, J.R., Jones, C.A., 1990. Demonstration and validation of crop grain yield simulation by EPIC. In: Sharpley, A.N., Williams, J.R. (Eds.), EPIC Erosion Productivity Impact Calculator, Model Documentation, USDA-ARS Tech. Bull. No. 1768, USDA-ARS Grassland, Soil and Water Research Laboratory, Temple, TX, pp. 220-234.

Lowenberg-DeBoer, J., Cherney, J.H., 1989. Biophysical simulation for evaluating new crops: the case of switchgrass for biomass energy feedstock. Agric. Systems 29, 233-246.

McCarl, B. A., Chang, C., Atwood, J.D., Nayda, W.I., 1998. Documentation of ASM: the US agricultural sector model. Dept. of Agric. Economics Technical Paper, Texas A\&M University, College Station, TX.

Mearns, L.O., Mavromatis, T., Tsvetsinskaya, E., Hays, C.J., Easterling, W.E., 1999a. Comparative responses of EPIC and CERES crop models to high and low spatial resolution climate change scenarios. In: Giorgi, F. (Ed.), New Developments and Applications with the NCAR Regional Climate Model (RegCM). J. Geophysical Res. 104(D6), 6623-6646.

Mearns, L.O., Easterling, W.E., Hays, C.J., 1999b. Comparison of agricultural impacts of climate change calculated from high and low resolution climate model scenarios: Part 1 . The uncertainty of spatial scale. Clim. Change, submitted.

Mearns, L.O., Giorgi F., Easterling, W.E., Weiss, A., 1996. Development of a nested regional model for the conterminous US and formation of high resolution climate change scenarios with an application to crop-climate models. In: Toward an Integrated Regional Research Program on Global Change and the Nation's Major Grasslands, Report GPRC 96-01, Great Plains Reg. Center for Global Env. Change, Inst. of Agriculture and Nat. Resources, Univ. of Nebraska, Lincoln, NE, pp. 47-50.

Mitchell, R., Moser, L., Anderson, B., Waller, S., 1994. Switchgrass and big bluestem for grazing and hay. NebGuide G94-1198-A. Coop. Extension, Institute of Agriculture and Natural Resources, Univ. of Nebraska, Lincoln, Nebraska.

Moulton, R.J., Richards, K.R., 1990. Costs of sequestering carbon through tree planting and forest management in the United States. US Dept. of Agriculture Forest Service Report GTR WO-58. Washington, DC.
Phillips, D.L., White, D., Johnson, B., 1993. Implications of climate change scenarios for soil erosion potential in the USA. Land Degradation and Rehabilitation 4, 61-72.

Ranney, J.W., Mann, L.K., 1994. Environmental considerations in energy crop production. In: Wright, L.L., Hohenstein, W.G. (Eds.), Dedicated Feedstock Supply Systems: Their Current Status in the USA, Biomass and Bioenergy 6, pp. 211-228.

Reese, R.A., Aradhyula, S.V., Shogren, J.F., Tyson, K.S., 1993. Herbaceous biomass feedstock production: the economic potential and impacts on US agriculture. Energy Policy 21, 726-734.

Richardson, C.W., Nicks, A.D., 1990. Weather generator description. In: Sharpley, A.N., Williams, J.R. (Eds.), EPIC Erosion Productivity Impact Calculator, Model Documentation, USDA-ARS Tech. Bull. No. 1768, USDA-ARS Grassland, Soil and Water Research Laboratory, Temple, TX, pp. 93-104.

Rosenberg, N.J., Scott, M.J., 1994. Implications of policies to prevent climate change for future food security. Global Environ. Change 4, 49-62.

Rosenberg, N.J. (Ed.), 1993. A methodology for assessing regional agricultural consequences of climate change: application to the Missouri-Iowa-Nebraska-Kansas (MINK) region. Agric. and For. Meteorology 59, 1-127.

Rosenberg, N.J., McKenney, M.S., Easterling, W.E., Lemon, K.M., 1992. Validation of EPIC model simulations of crop responses to current climate and $\mathrm{CO}_{2}$ conditions: comparisons with census, expert judgement and experimental plot data. In: Rosenberg, A., Methodology for Assessing Regional Agricultural Consequences of Climate Change: Application to the Missouri-Iowa-Nebraska-Kansas (MINK) Region. Agric. and For. Meteorology 59, 35-52.

Rosenzweig, C., Curry, B., Ritchie, J.T., Jones, J.W., Chou, T.Y., Goldberg, R., Iglesias, A., 1994. The effects of potential climate change on simulated grain crops in the United States. In: Rosenzweig, C., Iglesias, A. (Eds.), Implications of Climatic Change for International Agriculture: Crop Modeling Study. Report EPA 230-B-94-003, United States Environmental Protection Agency, Office of Policy, Planning, and Evaluation, Washington, DC.

Rosenzweig, C., 1989. Potential effects of climate change on agricultural production in the Great Plains: a simulation study. In: Smith, J.B., Tripak, D. (Eds.), The Potential Effects of Global Climate Change on the United States, Appendix C, vol. 1. United States Environmental Protection Agency, Office of Policy, Planning, and Evaluation, Washington, DC

Sampson, R.N., Wright, L.L., Winjum, J.K., Kinsman, J.D., Benneman, J., Kürsten, E., Shurlock, J.M.O., 1993. Biomass management and energy. Water, Air and Soil Pollution 70, 139-159.

Sedjo, R.A., Solomon, A.M.,1989. Climate and Forests. In: Rosenberg, N.J., Easterling, W.E. III, Crosson, P.R., Darmstadter, J. (Eds.), Greenhouse Warming: Abatement and Adaptation. Resources for the Future, Washington, DC, pp. 105-119.

Stockle, C.O., Williams, J.R., Rosenberg, N.J., Jones, C.A., 1992a. A method for estimating direct and climatic effects of rising atmospheric carbon dioxide on growth and yield of crops: Part 
I. Modification of the EPIC model for climate change analysis. Agric. Systems 38, 225-238.

Stockle, C.O., Dyke, P.T., Williams, J.R., Jones, C.A., Rosenberg, N.J., 1992b. A method for estimating direct and climatic effects of rising atmospheric carbon dioxide on growth and yield of crops. Part II. Sensitivity analysis at three sites in the Midwestern USA. Agric. Systems 38, 239-256.

USDA-National Agricultural Statistics Service, 1983-1993. Crops County Data Database. Washington DC.

USDA, 1992. STATSGO - State soils geographic data base. Publication number 1492, Soil Conservation Service, Washington, DC.

Vogel, K.P., 1996a. Genetic variation among switchgrasses for agronomic traits, forage quality and biomass fuel production - Annual Report for 1995. Biofuels Feedstock Development Program, Oak Ridge National Laboratory, Oak Ridge, TN.

Vogel, K.P., 1996b. Energy production from forages (or American agriculture - back to the future). J. Soil and Water Conservation 51, 137-139.
Watterson, I.G., Dix, M.R., Gordon, H.B., McGregor, J.L., 1995. The CSIRO nine-level atmospheric general circulation model and its equilibrium present and doubled $\mathrm{CO}_{2}$ climates. Aust. Met. Mag. 44, 111-125.

Williams, J.R., 1995. The EPIC model. In: Singh, V.P. (Ed.), Computer models of watershed hydrology. Water Resources Publications, Highlands Ranch, CO, pp. 909-1000.

Williams, J.R., Dyke, P.T., Fuchs, W.W., Benson, V.W., Rice, O.W., Taylor, E.D., 1990. EPIC - erosion productivity impact calculator: users manual. In: Sharpley, A.N., Williams, J.R. (Eds.), EPIC - Erosion Productivity Impact Calculator, Model Documentation, USDA-ARS Tech. Bull. No. 1768, USDA-ARS Grassland, Soil and Water Research Laboratory, Temple, TX, $127 \mathrm{pp}$.

Wright, L.L., Hohenstein, W.G. (Eds.), 1994. Dedicated feedstock supply systems: their current status in the USA, Biomass and Bioenergy 6, pp. 159-241. 